\title{
Creativity, Psychoanalysis and Eugene O'Neill's Creative Process
}

\author{
Asim Karim \\ Nasim Riaz Butt \\ English Department, Gomal University, Dikhan, Pakistan \\ English Department Punjab University Lahore, Pakistan \\ e-mails: asim.karim09@gmail.com \\ nasim-butt@hotmail.com
}

\begin{abstract}
O'Neill is undisputedly one of the most autobiographical artists in modern literature. His creativity consistently moves around subjective exploration and autobiographical representation in his art. Therefore drama for him involves primarily dramatization of self and close relations such as mother, father and brother, and this association between life and art goes back to early amateur plays. This factor has exposed the artist to discreet psychoanalytic explorations and analysis. Clearly a depressive and predominantly oedipal pattern emerges in his writings that could be traced in the whole range of his plays. However, preoccupation with the self and pervasive obsession to dramatize peculiar relationships and psychic conditions create its own archeology of limitations in his art that have remained unaddressed so far. The study debates on creativity, psychoanalytic traditions of creativity, O'Neill's creative process and highlights some of the limitations that pertain to representative and intellectual aspects of his art.
\end{abstract}

Key words: American drama, O'Neill's drama, creativity, psychoanalysis

There has been a lot of debate on what constitutes creativity and how it shapes in the artist's mind and imagination. The discussion has remained contentious and dates back to Plato and Aristotle whose diverse thoughts on art have become integral to any debate on the nature of art and literature itself. Modern psychology having its revolutionary model in Freud's expressive and dogmatic theories of human psychology provides new insight into the creative process. Viewed from one perspective that is quite independent of what modern psychology has to say about human consciousness, artist and literary creativity involve a definite process of 
understanding human nature, exploring human consciousness and even unconsciousness, evaluating his desires, frustration, thoughts etc. Literature in this respect is older than psychoanalysis itself. Sakura (1987) develops the argument that poets investigated the unconscious much earlier than Freud "and that at its subtlest and most wide ranging" (p. 4) which makes them "the literary predecessors of Freudian legacy" (p. 4). The artist's probing of human consciousness before the rise of modern psychoanalytic critical and theoretical approaches was largely in the nature of using psychology to study how the whole mind works or "for understanding an other human psyche"(p. 2). It did not address itself to study and analyze diseases or more properly speaking psychopathological states or primitive experiences and their effect on developmental, evolutionary and creative aspects of human behavior. It did not aim at "producing a certain kind of knowledge, providing explanations of human conduct and experience by revealing the mental forces that underlie them and can not be dealt with by any other intellectual discipline" (Frosh, 1987, p. 19). Sakura (1987) also writes about different ways of a poet and an analyst. She is of the opinion that "The primary connection between Freud and the poets is a shared mythology: a general insight into human nature, confrontation with experiences neither the poets nor Freud were afraid to see (p. 34). Tingle, Alcorn, and Bracher (1986) likewise support the close correspondence between literature and psychoanalysis. They argue that:

There are certainly many differences between teaching literature and conducting an analysis, but since the aim of both processes is ultimately the same -assisting humans to become more autonomous and fulfilled -what goes on in one can illuminate and inform what occurs in the other" (p. 96).

Wilbern (1989) takes the relationship between literature and psychology back to Greek classical period. "The ancient argument", he writes, "between Plato and Aristotle about the value of myth and drama is fundamentally a conflict between psychological assumptions and mimesis (p. 159). Guerin, Labor, Morgan, Reesman, and Willingham (1992) also look upon a psychoanalytical approach in terms of having ancient historical existence that finds an important place in theories of Aristotle, Sidney, Coleridge, Wordsworth, and Shelley regarding catharsis and imagination respectively (p. 117). 


\section{CREATIVITY AND PSYCHOANALYSIS}

The problem of any correlation/interaction between creativity and artist's psychology has been debated contentiously among the theorists and psychoanalysts. Kauffman and Baer (2002) for instance argue that those with mental illness particularly female poets are more likely to be drawn to poetry rather than to other forms of prose due to the personal nature of poetry. They conclude by stating, "The adage that creativity and 'madness' are linked together is by and large supported by the existing research" (p. 282). Wooster and Buckroyd (2006) in their study of Shakespeare's All's Well that Ends Well support the thesis that loss and creativity are often linked. First they define loss and mourning as a complex process affecting the mind and emotions:

Loss in real and metaphorical ways, as we know, provokes anger, guilt, and sadness. The grief of loss is a complex state of mind with different lengths of duration, and in each individual shows different mixes of other constituent affects, such as anger, guilt, and shame, mixed with envy and jealousy as well as frequently accompanying depression with varying degrees of somatic disruptions (p. 26).

Then they analyze the problem of co-relation between loss and creativity by probing some psychoanalytic ideas about creativity. They begin by considering Rothenberg's The Emerging Goddess (1979) as one of the most comprehensive descriptions of the common factors in creativity. They then consider the group in which grief, loss, and creativity can be expressed in different ways. Lastly, they examine Shakespeare, who for them is perhaps the most striking example of all these experiences and whose middle-period play All's Well That Ends Well binds together grief, loss, and creativity. Freud's "Creative Writers and Day-Dreaming", however, was the premier theoretical effort in relating psychology to literature. It gives us insight into what Freud thinks about the artistic creativity. "The creative writer," according to his classic essay on the subject, "does the same thing as a child at play. He creates a world of phantasy.... He builds castles in the air and creates what are called day-dream" (as cited in Strachey, 1953). He called it sublimation. Despite the inner contradiction his theory has acquired strong support among the theorists and critics across the globe. Fairberg (1960) for example points out that to some extent we all lead "a 
life of fantasy," and that our "civilized pursuits" on some level of sublimation serve to assuage our repressed infantile desires (pp. 42-43). This statement reinforces Freud's declaration of comparison between an artist and a neurotic. Wright also supports Freudian interpretation of creative process. She elaborates her stance with reference to Freudian concept of id-Psychology. The term Id-psychology was not used by Freud himself, but was adopted subsequently both by the critics and theorists to explain the role of sex as a determining force in human consciousness. Wright (1984) terms it "vulgar Freudianism" (p. 37) and writes, "The aesthetics of id-psychology is grounded on the notion that the work of art is the secret embodiment of the creator's unconscious desires" (p. 37) which is exposed through the analysis of his earliest childhood experiences through "what is known in his life and through the fictional characters" (p. 37). Kris (1952) has made considerable theoretical contributions in bringing about application of psychology to literature. He termed idpsychology grossly inadequate to explain the creative process. His theoretical orientation is that of ego psychology where he moves away "from the unconscious, infantile sources of creativity focused on by idpsychologists to concentrate on conscious, preconscious and rational thought process" (as cited Schneiderman, 1988, p. 8) in creativity which diminishes the importance of the repression and repressed sexual drives as the exclusive explanatory concepts of literary creativity. Likewise Schneiderman (1988) in his interpretative work strongly emphasizes the role of personal painful experiences (not necessary libidinal) in artistic creativity:

Admittedly old fashioned id psychology, with its emphasis on sexual symbolism and its penchant for body language, did not lend itself to a balanced interpretation of art. I, would argue, however, that the psychoanalytic study of literature cannot dispense with Freud's idpsychology and substitute an ego psychology that attributes complete rationality and conscious control to the artist. Such a view, in my judgment is out of human context (p. 20).

He continues to say that 'under the right conditions, the author's response to the challenges of everyday life result in artistic productions of great virtuosity" (p. 20). He points particularly severe stress as one of the "important ingredient in generating creativity" and that "one has to read one 
page of any outstanding modern writer to be struck by the intensity of the personal vision generated by the powerful inter-psychic forces, neither mysterious nor rational but rooted in human experience, especially crises and conflicts" (p. 20). Klein (1986) and Kristeva (1987) have further developed these thoughts on sublimation and artistic creativity. Klein in one of her most important papers "The Importance of Symbol Formation in the Development of Ego" refers to a schizoid-paranoid subject's tendency to engage in creative process in order to displace his ambivalent interest in the object (mother) and symbolizes these in the world which gives rise to his interest in the outside world. It is because the external world is endowed with symbolic meaning that it arouses our enormous interest, which is imperative for the purpose of survival. Klein writes, "Symbolism is the foundation of all sublimation and every talent, since it is by way of symbolic equation that things, activities and interests become the subject of libidinal phantasy (p. 97). Kristeva likewise in her essay "On the Melancholic Imaginary" (1987) establishes strong equation between personal loss and creative processes. In her essay on "Melancholic Imaginary" she returns to Freud's theory of mourning, and tries to examine the ways in which loss mobilizes the afflicted towards creativity. Here she refers to the peculiar role of pain in mobilizing the afflicted to the creative process. She writes:

We find ourselves here before an enigmatic chiasmus that will not cease to preoccupy us: if loss, mourning, absence set the imaginary act in motion and permanently fuel it as much as they menace and undermine it, it is also undeniable that fetish of the work of art is erected in disavowal of this mobilizing affliction (p. 105).

These dual responses of what she terms dejection and exultation and alteration between them "constitutes the depressive temperament of neurotic" (pp. 105-06). This commentary is followed by her detailed analysis of Dostoevsky in respect of the dual representation or responses. Dostoevsky' "tormented universe" (p. 115) caused more by his epileptic fits than just grief is reflective of this dialectic of responses. What she writes here is that pain, grief, loss or whatever the form of pain has the diverse role in creativity. It lies in either the acceptance or the denial of the underlying pain in what a writer creates. 
However, despite strong positions on interaction between artist psyche and what he/she creates, there are strong reservations as well. What an artist creates and what he intends to project can not be categorized as displacement, sublimation, transformation, or reflection of the hold of the infantile past over the present or symbol formation. Artistic creation is a subtle process and a complex blend of intellectual, emotive, unconscious irrational factors that makes it difficult to describe exactly what happens in the artist's mind or when does it happen. For Hoffman (1950), the complex intent of the artist which "immediately precedes the work" is far more important than the knowledge of his relation with his father and mother (p. 147). He terms Freudian interpretation of artistic creativity as "subversive application" of psychoanalytic criticism (p. 147). The work itself writes Hoffman is or should be of far greater importance than the circumstances which produced it and the "value of these circumstances is measured only by the degree of success, it has in clarifying the work and making it explicit and comprehensible" (p. 148).

\section{O'NEILL'S CREATIVE PROCESS}

Eugene O'Neill's creativity in the light of the above is an embodiment of subjectivism and self-reflectivity. He is one of the most vigorous autobiographical artists in modern literature. His plays are a record of personal life experiences and history Bogard, 1988, and Shaughnessy, 2002). Therefore drama for O'Neill involves primarily dramatization of self and close relations such as mother, father and brother, and this association between life and art goes back to early amateur plays. Walton (1955) explores a close association between his life experiences and his first twenty five plays following his association with Province Town Players from 1914-24, all dealing with "folklore and folkways of the sea- traditional sailor concepts and patterns of conduct he had learned from two years of firsthand experience aboard ocean going ships and in water front area before beginning his career as a dramatist" (p. 153). Walton (1955) includes Beyond Horizon, Diff'rent, Gold, Anna Christie, The Hairy Ape, and Ancient mariner among O'Neill first act plays in this category that deal with personally experienced sea ways. Alexander (1992) places her Eugene O'Neill's Creative Struggle: A Decisive decade, 1924-33 on the assurance that the plot, character and imagery of the plays that she has selected for This factor have been shaped by a "specific nexus of personal 
memories brought into concern with the personal in turn necessitated recollection and recreation of what actually transpired in his traumatic life at different stages" (p.21). Therefore his creativity or the creative process in his consciousness rotates strappingly around the past and memories, which are charged with repetition and reiteration of extraordinary nature and sequence. This detail reveals an almost pervasive obsession for dramatizing self and also near ones especially mother, father and elder brother in his plays, which has exposed O'Neill as a man and artist to multiple theoretical and critical interpretations. The self here is shaped by the unconscious drives which serve as the main source of mobilizing his creative impulses and imaginative reflections. As the artist's unconscious here is in traumatized state for the reason referred below, the art itself assumes “depressive attribution style" (Brown, 1991 p. 51). O'Neill's creativity in the context of co-existence of close relationship between his personal afflictions and creative urges and the creative impulse inspired by affliction was not for any attempt on the part of the playwright to resolve the crises as Alexander (1992) argues. On the contrary it remains unresolved and keeps the creative process entangled in restructuring the personal loss and recovering the lost object/being (here mother) for particular psycho-sexual imperatives (Moorton Jr., 1991, Bogard 1988). The natural consequence of this dimension of creativity creates persistent mode of loss and depressiveness in the whole range of his art. This particular mode of creative process highlights two related factors in his art. First art is an apt reflection of psychopathological identity of the suffering artist. Secondly the exclusive and persistent focus on the unconsciousness invests his whole art with pessimistic rather sadistic impression and instructs his plays with certain aesthetic limitations. These limitations have been highlighted in terms of its representative quality and intellectual appeal:

1. Persistency of the affliction as a mobilizing agent restrains the artist's imagination, creating total absorption in the personal/ private to the dismemberment of the higher aesthetic ideals of universal application and appeal. O'Neill was a keen experimentalist as well as a reflective artist. His reflections on what he wanted to achieve in the theatre could be found in his notes, letters and his work diaries in bits and pieces. In one of his letter to Hobson Quinn wherein O'Neill refers to the mysterious force: 
Fate God our biological past creating our present, whatever one calls it_ Mystery, certainly) - and "of the one eternal tragedy of Man in his glorious self destructive struggle to make the Force express him instead of being as an animal is, an infinitesimal incident in its expression (Bogard and Bryer, 1988, p. 195).

In the same letter he wishes to depict not a slice of human life, but an understanding of life's spirit "life in term of lives, never just life in terms of character" (p. 195). Here there is, as Tornquist (1969) comments, a curious blend of mystical, scientific views and metaphysical language that aims at establishing some sort of corollary between the classic and the contemporary idioms in tragedy. The fusion, however, far from creating harmony between the two, highlights important dichotomy between the classic and his modern theatre. Action in Greek tragedy springs from the character as a complex of human traits shaped by past human experience or as the product of working of metaphysical forces such as a reaction against human breach of cosmic order. But the action whatever the shaping spirit may be remains recognizable, rationalistic and continue to reflect the laws of human experience. Besides, the ultimate expression of the human predicament in tragedies is far from self-destructive, defeatist and enfeebling. O'Neill's concern with the internal on the other hand as Tornquist (1969) argues blends with modern scientifically interpreted but anti-rationalistic psychological forces. The fusion has a counter effect on human endeavor to live. It makes his struggle assume self destructive, defeatist with depressive and enfeebling effect on the character's behavior. The emergent impression undermines applicability and appeal $\mathrm{f} \mathrm{his} \mathrm{art} \mathrm{in} \mathrm{wider} \mathrm{terms.}$

2. It is undeniable that a tragic event always involves suffering for the protagonist and the related personas. Sufferings in fact constitute undisputedly the crux of tragedy and generally but not necessarily end in the protagonist's death. They have generally their origin in man's own disposition and may work in collusion with the external forces to accentuate their destructive effect for that individual. A perfunctory glance on the bulk of tragic works makes it very clear that tragedy without corresponding suffering is hardly a thinkable reality. Sufferings in O'Neill's dramatic art bear a characteristic stamp. Their store house either lies in the character's total absorption in the realization of certain 
personal desires of erotic nature or in some other extreme modes such as guilt, illusiveness, loss, and alienation, springing from a man's disposition to repeat them with a high degree of ambivalence. What is to be found in for instance Desire under Elms, Strange Interlude is an absolute preoccupation with sexuality to the level of self-indulgence which is an expression of undermining faith in human potentiality and propensity to achieve personal, emotive, and psychic transcendence (Karim and Butt, 2011). This particular static impression governs even human relationships in his plays. Relationships in O'Neill's art manifest their control by the consciousness or deeper unconsciousness. The personas are locked in conflict with the others in such a way that they seem to be governed and shaped by the inner forces of incest, sexuality, jealousy, guilt, desire, or the life and death instincts. In Strange Interlude, for instance, Nina's extra marital relationship with Darrel is shaped by her desire to give birth to a biologically healthy child (Karim, 2010). Likewise all incest motives in Strange Interlude, Mourning Becomes Electra, Long Day's Journey and A Touch of Poet precede the necessity to create and foster a particular relation. Thus, the relationships in O'Neill are not the representation of a family drama; they are personal and an example of what Williams (1966) calls "private tragedy" (p.106).

Importantly such sufferings do not carry the element of transference from the stage to the audience. Drama by virtue of its stage production does embody the vibrant presence of the audience and their periodic emotive involvement at different stages denotes general applicability of that very production. Then the audience is not to be confined to a time frame say of the artist's own age. The timelessness of the art necessitates the measurement of response of the audience of different ages and regions. Overt sexual indulgence or its suppression and the resulting neurasthenia may have the emotional interest of a group at any particular time period and area, but can not be generalized. In diverse culture with diverse values and systems the particular focus on the control of the unconsciousness for specific relationship patterns is likely to create deeper inter-cultural misperceptions and conflicts.

3. Then plays where psychopathology is uppermost, which begin with the present and advance by returning into the past in a repetitive fashion can be stimulating and stirring experiences, but they fail to create intellectual absorption that has remained the essence of real tragic 
drama. Shakespeare's Hamlet is the play about which there is most disagreement. It has generated bewildering variety of different and even contradictory responses for Hamlet as a tragic hero, from being considered as the greatest tragic hero to that of "neurotic" (Knight, 1977, p. 17). His agony, self-torture, is beyond any doubt stupendous, generating in him thought of unprofitability of life "an unweeded garden," where" rank and gross" things grow. Intensity of pain and grief drive him to the state of negation of life and death, a state of "to be or not to be". But the overall effect is not one of loss, emptiness and pettiness of human endeavor. Hamlet still retains the grandeur of tragic hero. Turner (1971) describes his struggle allegorically at two levels,

Hamlet must act in relation to two worlds; the world of time in which the crime was committed and within which he must work his revenge, and the timeless world where he has been shown the crime and commanded to revenge it" (p. 69).

He goes on to write that, "Hamlet is trapped in time. ... the command of revenge and implications of its source seem to require an action which is timeless, which will destroy not only an individual evil but evil itself ... (p. 89). This allegorical interpretation is one among scores of interpretations of this great tragedy. The gravity of the struggle, if looked in this perspective acquires a great educative value where human struggle is not one of the survivals to carry on empty existence. The quality of endeavor regardless of the fate that the hero faces is essentially transcendental. The reader, therefore, returns again and again to tragedies like Hamlet grasping some eternally fixed beauty or immutable truths encapsulated in them. Tragedies pose problems and questions of fundamental as well as eternal human significance, and it is in reading and responding to the continually challenging questions set in motion by these plays that tragedy is truly performed and experienced. The overall impression and response is one of what Kierkegaard said about life in general in his existential notions: "The sickness unto Death" or that of "Conscience is a disease" (as cited in Szeliski, 1962, p. 58). Finally the calamitous sufferings caused by nature or uncontrolled forces of either past or present may bring out some sort of sympathy with the sufferer, but as Eldridge (1994) writes, "we are typically not instructed about human nature by them" (p. 292). 


\section{CONCLUSION}

O'Neill's preoccupation with loss and subjective experiences raises certain important questions for further discussion. They are:

1. Thanks the development in modern psychology, it has become difficult to stay away from conclusion that psychopathology is inseparable from creativity. In fact the modern and post-modern drama representation of "mental theatre" (Pizzato, 1998, p. 5) highlights the fallacy and ineffectiveness of denunciating the role of artist's subjective self in what $\mathrm{s} / \mathrm{he}$ creates. It seems that undermining of literary text as an embodiment of author's vision and unconsciousness has gone predominantly unnoticed. The author remains a focus of interpretative attempts and marks an important part of the readers' efforts in comprehending the text as well as the technique. However, the issue is not altogether free from complexities and has remained very controversial, refusing to settle into a single accepted formula and notional position.

2. O'Neill's subjective drama is also an instance of what options are left to the modern writers in the modern society that provides little support to the artist's exercise of imagination and who is being increasingly put under pressure to cater to the popular tastes. With the incessant explosion of intellectual and artistic production catering to the popular culture and tastes, the creative writer can only satisfy his imaginative craving and intellectual stimulation or create art by turning his imagination, impulses, thoughts, drives, and emotions upon himself to find both inspiration and raw material for the works for his themes and characters, and if the author's inner self has experienced, and sustained pain of various categories, that pain finds outlet in his creative works.

3. O'Neill's preoccupation with affliction in a particular fashion signifies the need to discuss further the role of pain in creativity. It cannot be said that personal grief always results in deploringly dark vision of the entire human life and nature. Moreover creativity generated by pain is not always and necessarily subversive, dehumanizing, degenerative and static. There is a possibility when the writer transcends the confines of personal pain and unconscious to create an image of aesthetic beauty that is artistic, imaginative, and inspirational and transcends the confines of time and achieve the highest degree of objectivity. In O'Neill on the other hand personal crises, painful subjective 
experiences and the predominance of the unconsciousness structure the entire thought patterns with a constrictive dimension.

\section{REFERENCES}

Alexander, D. (1992). Eugene O'Neill's creative struggle: The decisive decade, 1924-1933. Pennsylvania: The Pennsylvania State University Press.

Bogard, T. (1988). Contour in time: The plays of Eugene O'Neill. New York: Oxford University Press.

Bogard, T., \& Bryer, J. (Eds.). (1988). Selected letters of Eugene O'Neill. London: Yale University Press

Brown, R. (1991). Causality in O'Neill's late masterpieces. In R.F. Martoon, Jr. (Ed.), Eugene O'Neill's century: Centennial views on America's foremost tragic dramatist (pp. 41-54). London: Greenwood Press.

Eldridge, R. (1994). How can tragedy matter for us? The Journal of Aesthetics and Art Criticism, 52(3), 287-298.

Fairberg, L. (1960). Psychoanalysis and American literary criticism. Detroit: Gale.

Frosh, S. (1987). The politics of psychoanalysis: An introduction to Freudian and post Freudian theory. London: Macmillan.

Guerin, W. L. et al. (1992). A handbook of critical approaches to literature (3rd ed.). New York: Oxford University Press.

Hoffman, F.J. (1950). Psychoanalysis and literary criticism. American Quarterly, 2(2), 144-154. Retrieved from http://www.jstor.org/stable/3031451

Karim, A. (2010). Eugene O'Neill's concern with sexuality and the behavioral disorders. Studies in Literature and Language, 1(1), 38-49.

Karim, A. \& Butt, N.R. (2011). Ethical crises in O'Neill's modern theatre: Some dimensions. Arts and Social Sciences Journal, 2011: ASSJ-32, 1-16. Retrieved from http://astonjournals.com/assjvols.html

Kauffman, J.C \& Baer, J. (2002). I bask in dreams of suicide: Mental illness, poetry and women. Review of General Psychology, 6, 271-186.

Klein, M. (1986). The selected Melanie Klein. (J. Mitchell, Ed.). New York: Free Press.

Knight, G.W. (1977). The wheel of fire: Interpretation of Shakespearian tragedy with three new essays. London: Methuen

Kristeva, J. (1987). On the melancholic imaginary. In S.R.-Kenan (Ed.), Discourse in psychoanalysis and literature (pp. 104-123). London: Methuen.

Pizzato, M. (1998). Edges of loss: From modern drama to postmodern theory. An Arbor: The University of Michigan Press.

Sakura, M. (1987). The literary use of psychoanalytic process. New Heaven: Yale University Press. 
Schneiderman, L. (1988). The literary mind: Portraits in pain and creativity. New York: Insight Books.

Shaughnessy, E. L. (2002). Down the nights and down the days: Eugene O'Neill's catholic sensibility. Notre Dame: University of Notre Dame Press.

Strachey, J. (1953). The standard edition of complete psychological works. London: Hogarth Press.

Szeliski, J.V. (1962). Tragedy and fear: Why modern tragic drama fails. Chapel Hills: The University Of North Carolina Press.

Tingle, N., Alcorn, M.W., Jr., \& Bracher, M. (1986). Literature and psychoanalysis. PMLA, 101 (1), 95-97. Retrieved from http://www.jstor.org/stable/462538.

Tornquist, E. (1969). A drama of souls: Studies in O'Neill's super-naturalist technique. New Haven: Yale University Press.

Turner, F. (1971). Shakespeare and the nature of time: Moral and philosophical themes in some plays and poems of William Shakespeare. Oxford: Clarendon Press.

Walton, I. H. (1955). Eugene O'Neill and the folklore and folkways of the sea. Western Folklore. 14(3), 153-169.

Wilbern, D. (1989). Reading after Freud. In G.D. Atkins \& L. Morrow (Eds.), Contemporary literary theory (pp. 158-179). London: Macmillan.

Williams, R. (1966). Modern tragedy. London: Hogarth Press.

Wooster, G. \& Buckroyd, P. (2006). Grief, loss, and creativity: Whither the phoenix? In I. Wise \& M. Mills (Eds.), Psychoanalytic ideas and Shakespeare (pp. 25-41). London: H. Karnac (Books) Ltd.

Wright, E. (1984). Psychoanalytic criticism: Theory in practice. London: Methuen. 